\title{
Regulation of Leydig cells through a steroidogenic acute regulatory protein-independent pathway by a lipophilic factor from macrophages
}

\author{
Y O Lukyanenko, A M Carpenter, D E Brigham, D M Stocco and \\ J C Hutson
}

Department of Cell Biology and Biochemistry, Texas Tech University Health Sciences Center, Lubbock, Texas 79430, USA

(Requests for offprints should be addressed to J C Hutson)

\begin{abstract}
The purpose of this investigation was to study the mechanism of action of a macrophage-derived factor that stimulates steroid production by Leydig cells. This factor increased testosterone production within $30 \mathrm{~min}$, and reached a half-maximal response by $6-8 \mathrm{~h}$. At a maximal dose, it stimulated testosterone production 20 -fold at $24 \mathrm{~h}$. Its efficacy was consistently higher than that achieved with a maximal dose of human chorionic gonadotropin (hCG). However, Leydig cells treated with a maximal dose of both the macrophage-derived factor and hCG secreted the same amount of testosterone as when given a maximal dose of only the macrophage-derived factor. The
\end{abstract}

macrophage-derived factor did not require new protein synthesis to stimulate testosterone production, nor did it alter the amount of steroidogenic acute regulatory protein (StAR). While the macrophage-derived factor required an active cholesterol side-chain cleavage complex system, it did not alter the capacity of this enzyme complex. Finally, the macrophage-derived factor was unable to stimulate the production of progesterone by isolated mitochondria. In summary, the macrophage-derived factor is a highly active, acute regulator of steroidogenesis that acts through a high capacity StAR-independent pathway.

Journal of Endocrinology (1998) 158, 267-275

\section{Introduction}

Recent evidence substantiating a paracrine interaction between macrophages and Leydig cells has been provided by clever experiments involving the experimental depletion of macrophages using toxins. For example, when macrophages were unilaterally depleted from the testis using liposome-encapsulated clodronate (Bergh et al. 1993), or by injecting unencapsulated silica (Huhtaniemi et al. 1986), testosterone levels within that testis were lowered. It is likely that this effect is in response to the elimination of macrophages, since macrophages preferentially phagocytose these liposomes (for an excellent review on this system see van Rooijen \& Sanders 1997), and because it has been shown that these liposomes do not have a direct influence on Leydig cells (Brigham et al. 1997). However, when macrophages are depleted from both testes, testosterone levels rise significantly (Gaytan et al. 1996). While the reason for this seemingly contradictory result is unknown, it was speculated that macrophages may also play a role in the central regulation of luteinizing hormone $(\mathrm{LH})$ secretion since these animals also had high levels of LH. In a second set of elegant in vivo experiments, it has been found that mice expressing a mutant form of colony stimulating factor-1 (CSF-1) were deficient in tissue macrophages, and had lowered levels of testosterone and reduced fertility (Cohen et al. 1996, Pollard 1997). When biologically active CSF-1 was given to these animals, macrophages populated the tissues, and fertility and testosterone production were restored (Cohen et al. 1996). Through these in vivo studies it seems clear that macrophages are involved in regulating Leydig cells.

Studies concerning the interactions between macrophages and Leydig cells have also been conducted in vitro, and indicate that the role of macrophages in the testis may be very complex involving both inhibitory and stimulatory factors. For example, interleukin-1 (IL-1) and tumor necrosis factor- $\alpha$ (TNF $\alpha$ ) have been shown to be produced by testicular macrophages (Hutson 1993, Xiong \& Hales 1993, Moore \& Hutson 1994, Kern et al. 1995, Hayes et al. 1996) and have been found in most studies to inhibit testosterone production by Leydig cells (for reviews see Hutson 1994, Hales 1996, Hedger 1997). One study reported that IL-1 could stimulate steroidogenesis under basal conditions or in the presence of low concentrations of LH (Verhoeven et al. 1988). Culture medium from testicular macrophages has also been found to contain a secreted factor that directly stimulated the production of testosterone by cultured Leydig cells (Yee \& Hutson 
1985). This factor has been isolated from macrophageconditioned medium by extraction with organic solvents, and subsequently purified by high performance liquid chromatography (HPLC) (Hutson et al. 1996). With the availability of this highly purified preparation, the present study was undertaken to gain information concerning its mechanism of action on Leydig cells.

\section{Materials and Methods}

\section{Materials}

Adult Sprague-Dawley rats (300-500 g body weight) were obtained from Harlan Sprague-Dawley (Minneapolis, MN, USA). Dulbecco's modified Eagle's/Ham's F12 medium (DME/F12), Waymouth's medium, Dulbecco's phosphate-buffered saline (PBS), bovine serum albumin (Fraction V, BSA), 22R-hydroxycholesterol (22R-OHC), newborn calf serum (NCS), horse serum, collagenase (Type I), penicillin, streptomycin, aminoglutethimide, cycloheximide, and dibutyryl cyclic AMP (dbcAMP), and other routine buffers and chemicals were all obtained from Sigma Chemical Co. (St Louis, MO, USA). Thioglycollate broth was obtained from Difco Laboratories (Detroit, MI, USA). Percoll was obtained from Pharmacia (Uppsala, Sweden). Human chorionic gonadotropin (hCG) was a generous gift from the National Hormone and Pituitary Program of the NIDDK (Bethesda, MD, USA). The $100 \mathrm{~mm}$ diameter culture dishes (\#3001) were obtained from Becton Dickinson Labware (Franklin Lakes, NJ, USA). The 96-well plates (\#25860) were obtained from Corning Glass Works (Corning, NY, USA). The testosterone and progesterone radioimmunoassay components (Coat-a-Count tubes and tracers) were purchased from Diagnostics Products (Los Angeles, CA, USA). The MA-10 cells were a generous gift from Dr Mario Ascoli, University of Iowa, USA.

\section{Cell isolation and culture}

Testicular macrophages Testicular macrophages were isolated as previously described (Hutson et al. 1996) except that DME/F12 containing $0 \cdot 1 \% \mathrm{BSA}, 100 \mu \mathrm{g} / \mathrm{ml}$ streptomycin and 100 units/ml penicillin was used as the culture medium (medium). Cells were cultured in $100 \mathrm{~mm}$ dishes in $6 \mathrm{ml}$ medium containing 10\% NCS for 2 days. This medium was then used for purification of the macrophage-derived factor (see below).

Elicited peritoneal macrophages Rats received intraperitoneal injections of 3\% thioglycollate broth in PBS under light ether anesthesia. After 3 days, they were killed by $\mathrm{CO}_{2}$ asphyxiation and peritoneal macrophages were lavaged from the peritoneum using $20 \mathrm{ml}$ medium. The cells were allowed to attach to $100 \mathrm{~mm}$ dishes for $1-2 \mathrm{~h}$. The medium was then removed, and $6 \mathrm{ml}$ fresh medium containing 10\% NCS was added. After 2-3 days the medium was used for purification of macrophage-derived factor (see below).

Leydig cells Leydig cells were isolated as previously described (Hutson et al. 1996) using the same culture medium as described above for the testicular macrophages. For all experiments designed to assess the effects of the macrophage-derived factor on testosterone production, Leydig cells were maintained in 96-well plates $(50 \mu \mathrm{l}$ medium/well). For the experiments to determine if the production of the steroidogenic acute regulatory protein (StAR) was altered by the macrophage-derived factor, Leydig cells were maintained in $100 \mathrm{~mm}$ diameter culture dishes $(6 \mathrm{ml}$ medium/dish). After $24 \mathrm{~h}$ in culture, the medium was changed and experiments were begun.

MA-10 cells MA-10 cells were maintained in Waymouth's medium in $15 \%$ horse serum in $75 \mathrm{~cm}^{2}$ flasks for several passages and then transferred to either 24-well plates $(300 \mu \mathrm{l} /$ dish $)$ to determine the effects of the lipid on progesterone production, or into $100 \mathrm{~mm}$ diameter Petri dishes $(5 \mathrm{ml}$ medium/dish) to determine the effect of the factor on production of the StAR protein. Cells were maintained in culture $24 \mathrm{~h}$ prior to beginning the experiment. The culture medium was never allowed to become acidic, either prior to, or during an experiment.

\section{Purification of the macrophage-derived factor}

Our initial goal was to scale-up the purification procedure in order to obtain a sufficient amount of the factor to conduct all of the studies using the same preparation. While it had previously been shown that peritoneal macrophages do not produce this factor when grown under serum-free conditions (Hutson et al. 1996), we have recently found through preliminary studies that they produce significant amounts of the factor when grown in the presence of either fetal bovine serum, or newborn calf serum. We also determined that the macrophage-derived factor is not present in serum. The factor obtained from peritoneal macrophages is the same as produced by testicular macrophages in that it: (1) stimulates testosterone production by Leydig cells, (2) is extractable with ether, and (3) has elution profiles on both the $\mathrm{C}_{18}$ and silica high performance liquid chromatography (HPLC) columns that are identical to the testicular macrophage-derived factor. Further evidence that the same factor is produced by both testicular and peritoneal macrophages is provided by pilot experiments from the present studies demonstrating that the testicular macrophage-derived factor has the same response on Leydig cells when tested in the presence of 
aminoglutethimide or cycloheximide, as reported herein for the factor obtained from peritoneal macrophages.

Media from peritoneal and testicular macrophages were collected separately and subjected to the same procedure previously reported for purification of the macrophagederived factor (Hutson et al. 1996). Briefly, this involved ether extraction, fractionation on a $\mathrm{C}_{18}$ HPLC column using a methanol/water gradient, followed by further purification on a silica HPLC column using hexane/ isopropyl alcohol as the mobile phase. We arbitrarily defined ' 1 unit' as the amount of factor obtained from $35 \mathrm{ml}$ macrophage-conditioned medium. This amount (1 unit/ml) produced a near maximal response after $24 \mathrm{~h}$ exposure to Leydig cells.

\section{Effects of the macrophage-derived factor on Leydig cell viability}

Leydig cells were cultured in the presence of $1 \mathrm{unit} / \mathrm{ml}$ macrophage-derived factor for $18-24 \mathrm{~h}$ and then the cells were stained for $3 \beta$-hydroxysteroid dehydrogenase activity (Hutson 1989). The percentage of positive cells was determined by counting cells with an inverted phasecontrast microscope fitted with a gridded eyepiece calibrated to a stage micrometer.

\section{Dose-response studies}

To determine the dose-response kinetics of the macrophage-derived factor, Leydig cells were cultured for $17 \mathrm{~h}$ in medium with various amounts of the macrophagederived factor $(0 \cdot 125,0 \cdot 25,0 \cdot 5,1,3,5$ and 10 units $/ \mathrm{ml})$ or hCG $(0 \cdot 001,0 \cdot 01,0 \cdot 1,1,10$ and $50 \mathrm{ng} / \mathrm{ml})$. The concentration of testosterone in the medium was then determined.

\section{Time-response studies}

Leydig cells were cultured with the macrophage-derived factor (1 unit $/ \mathrm{ml})$, or hCG (10 ng/ml) for $0,0 \cdot 5,1,1 \cdot 5,2$, $4,6,8,12$ and $24 \mathrm{~h}$. The concentration of testosterone in the medium was then determined.

\section{Combined effect of the macrophage-derived factor and hCG}

Leydig cells were cultured with a maximal dose of the macrophage-derived factor ( 3 units $/ \mathrm{ml}$ ) and increasing doses of hCG $(0 \cdot 1,1$, and $10 \mathrm{ng} / \mathrm{ml})$. The concentration of testosterone in the medium was then determined after 6 and $24 \mathrm{~h}$.

\section{Effects of the macrophage-derived factor in the presence of a protein synthesis inhibitor}

Because LH/hCG is known to require new protein synthesis to alter steroidogenesis (Janszen et al. 1976, 1977), we wanted to determine if the macrophage- derived factor was also active in the presence of cycloheximide. Leydig cells were cultured for 2 or $6 \mathrm{~h}$ in the presence of either hCG $(10 \mathrm{ng} / \mathrm{ml})$, or the macrophagederived factor $(1$ unit $/ \mathrm{ml})$. In both treated and control groups, cycloheximide was added in various concentrations $(0,0 \cdot 1,1$ and $10 \mu \mathrm{M})$. The concentration of testosterone in the medium was then determined.

\section{Effects of the macrophage-derived factor on the production of} StAR

Because StAR plays a critical role in the regulation of steroidogenesis in response to LH/hCG (Stocco \& Clark 1996), we were interested in determining if the macrophage-derived factor also increased the production of StAR in both rat Leydig cells and in MA-10 cells. Leydig cells were cultured in the presence of either hCG $(10 \mathrm{ng} / \mathrm{ml})$, or the macrophage-derived factor (1 unit $/ \mathrm{ml})$ for $6 \mathrm{~h}$. The amount of cellular StAR, and the concentration of testosterone in the medium were then determined from whole cell extracts by immunoblot analysis using a polyclonal antibody to StAR as previously described (Clark et al. 1994). The optical densities of the bands representing StAR were evaluated using the Bioimage Visage 2000 Computer Assisted Image Analysis System (Ann Arbor, MI, USA). Results from this analysis are plotted as integrated optical densities (IOD) on an arbitrary scale set specifically for each film depending upon the amount of StAR loaded on the gel, and according to the length of time the blot was exposed to film. MA-10 cells were cultured in $100 \mathrm{~mm}$ diameter Petri dishes (approximately one-half confluent) in the presence of either dbcAMP $(1 \mathrm{mM})$ or the macrophage-derived factor (1 unit/ml) for $6 \mathrm{~h}$. The amount of mitochondrial StAR was determined as described above. The amount of testosterone (Leydig cells) or progesterone (MA-10 cells) was determined at the end of both of the experiments described above, to document that the lipid was capable of eliciting a biological effect in each specific experiment.

\section{Studies to determine if the macrophage-derived factor requires an active cholesterol side-chain cleavage complex (CSCC)}

Leydig cells were cultured for $6 \mathrm{~h}$ in the presence of either hCG $(10 \mathrm{ng} / \mathrm{ml})$, or the macrophage-derived factor (1 unit/ml) with and without aminoglutethimide (4, 40, and $400 \mu \mathrm{M})$, a known inhibitor of cholesterol side-chain cleavage activity (Uzgiris et al. 1977). The concentration of testosterone in the medium was then determined.

\section{Studies to determine if the macrophage-derived factor alters the} capacity of the CSCC

Leydig cells were cultured for $6 \mathrm{~h}$ in the presence of either hCG $(10 \mathrm{ng} / \mathrm{ml})$, or the macrophage-derived factor (1 unit/ml) with or without 22R-OHC $(12 \cdot 5,25$, and 
$50 \mu \mathrm{M}) .22 \mathrm{R}-\mathrm{OHC}$ is a compound useful for measuring the capacity of the CSCC system since it has direct access to the CSCC enzymes without requiring transport from the outer to the inner mitochondrial membranes (van Haren et al. 1992). The concentration of testosterone in the medium was then determined.

Studies concerning the effects of the macrophage-derived factor on isolated mitochondria

MA-10 cells were grown to subconfluent conditions and then scraped from the dishes in ice-cold phosphatebuffered saline. The cells were then homogenized in

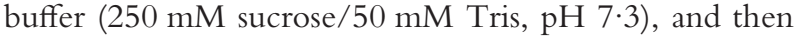
the unbroken cells, nuclei, and debris were removed by centrifugation at $800 \mathrm{~g}$ for $30 \mathrm{~min}\left(4^{\circ} \mathrm{C}\right)$. The supernatant was spun at $8000 \mathrm{~g}$ for $30 \mathrm{~min}$ to collect the mitochondria. The pellet of mitochondria was then resuspended in incubation buffer $(250 \mathrm{mM}$ sucrose, $10 \mathrm{mM}$ potassium phosphate, $15 \mathrm{mM}$ triethanolamine hydrochloride, $20 \mathrm{mM} \mathrm{KCl}, 5 \mathrm{mM} \mathrm{MgCl}_{2}$, and $10 \mu \mathrm{M}$ trilostane, $\mathrm{pH} 7 \cdot 2$ ) at a concentration of $1 \mathrm{mg}$ protein $/ \mathrm{ml}$. Aliquots $(100 \mu \mathrm{l})$ of the mitochondria preparation were then incubated at room temperature with: (1) incubation buffer, (2) $22 \mathrm{R}-\mathrm{OHC}$ $(25 \mu \mathrm{M})$, or (3) the macrophage-derived factor (1 unit/ml) for $1 \mathrm{~h}$. The mitochondria were then removed by centrifugation $(10000 \boldsymbol{g}$ for $20 \mathrm{~min}$ ) and the supernatant assayed for progesterone by RIA.

\section{Statistics}

Statistical significance $(P<0 \cdot 05)$ was determined by ANOVA and appropriate post-hoc analysis. Data are plotted as the mean \pm S.E.

\section{Results}

\section{Analysis and illustration of data}

Because of high interassay variability, a representative experiment for each phase of the study was illustrated rather than combining results from all experiments. Thus, the statistics represent variations within these representative experiments. However, all experiments were repeated at least three times with similar results, except for the StAR studies in which only two experiments were conducted and illustrated.

\section{Effects of the macrophage-derived factor on Leydig cell viability}

The number of $3 \beta$-hydroxysteroid dehydrogenase positive cells was not influenced by the macrophage-derived factor. The values for the control cells were $57 \cdot 5 \pm 0 \cdot 7 \%$ (mean \pm s.E.M.), and the values for cells treated with the macrophage-derived factor were $57 \pm 6.9 \%$.

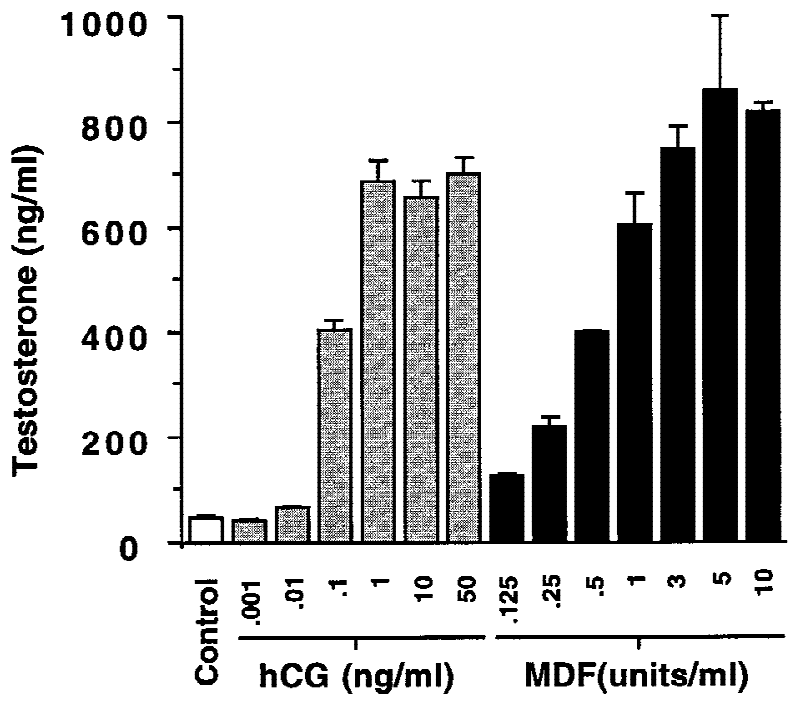

Figure 1 Production of testosterone by Leydig cells in response to increasing doses of hCG, or the macrophage-derived factor (MDF) for $17 \mathrm{~h}$.

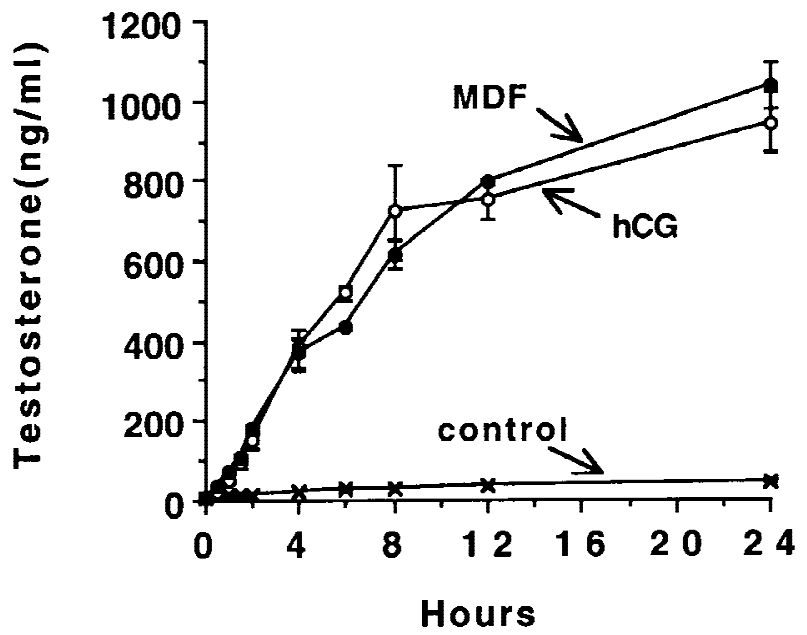

Figure 2 Time course for the production of testosterone by Leydig cells in response to hCG $(10 \mathrm{ng} / \mathrm{ml},(\bigcirc))$, or the macrophage-derived factor (MDF, $1 \mathrm{unit} / \mathrm{ml},(\mathbf{O})$ ).

Dose- and time-response studies

At maximal doses (approximately 1-10 units $/ \mathrm{ml}$ ), the macrophage-derived factor elicited approximately a 15-fold increase in testosterone production (Fig. 1). The least effective dose of the macrophage-derived factor was $0 \cdot 25$ units $/ \mathrm{ml}$. When tested at $1 \mathrm{unit} / \mathrm{ml}$, the macrophagederived factor increased testosterone production by $30 \mathrm{~min}$ and reached a half-maximal response by $6-8 \mathrm{~h}$ (Fig. 2).

Testosterone production in the presence of a maximal dose of both hCG and the macrophage-derived factor was the same as when only a maximal dose of the macrophage- 


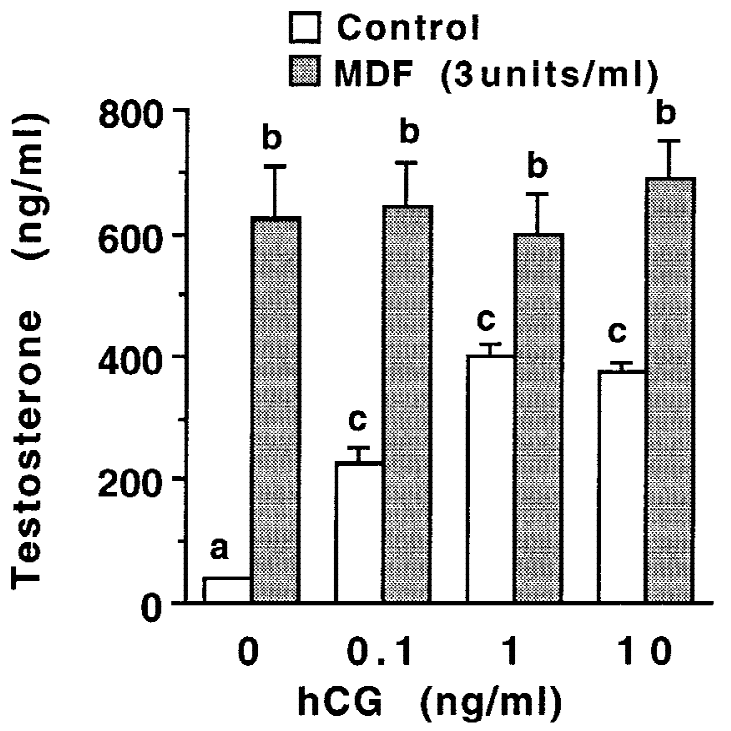

Figure 3 Combined effect of hCG and the macrophage-derived factor (MDF). Leydig cells were cultured in the presence of maximal doses of MDF ( 3 units $/ \mathrm{ml}$ ) and increasing doses of hCG $(0 \cdot 1,1$ and $10 \mathrm{ng} / \mathrm{ml})$ for $24 \mathrm{~h}$. Means with different letters are statistically different at $P<0 \cdot 05$.

derived factor was used following $24 \mathrm{~h}$ treatment (Fig. 3). Similar results were obtained at $6 \mathrm{~h}$ (data not illustrated).

\section{Effect of the macrophage-derived factor in the presence of cycloheximide}

The macrophage-derived factor elicited a steroidogenic response in rat Leydig cells in the presence of cycloheximide at $2 \mathrm{~h}$ (Fig. 4). Similar results were obtained at $6 \mathrm{~h}$ (data not shown). Cycloheximide had no effect on testosterone production by Leydig cells under basal conditions. In contrast, cycloheximide partially blocked testosterone synthesis in response to hCG at a dose of $1 \mu \mathrm{M}$, and completely blocked its effect at $10 \mu \mathrm{M}$, demonstrating that a sufficient dose of cycloheximide had been used. Cycloheximide was also unable to block the effects of the factor obtained from testicular macrophages when tested under similar conditions (data not shown).

\section{Effect of the macrophage-derived factor on StAR production}

The amount of StAR in cells treated with the macrophage-derived factor was not different from that in untreated rat Leydig cells (Fig. 5A). However, hCG elicited a marked response when tested under identical conditions indicating that the Leydig cells were responsive. Even though StAR levels did not increase in response to the macrophage-derived factor, testosterone production increased approximately 29-fold (control, $2 \cdot 1 \mathrm{ng} / \mathrm{ml}$; macrophage-derived factor, $57 \cdot 1 \mathrm{ng} / \mathrm{ml}$ ).

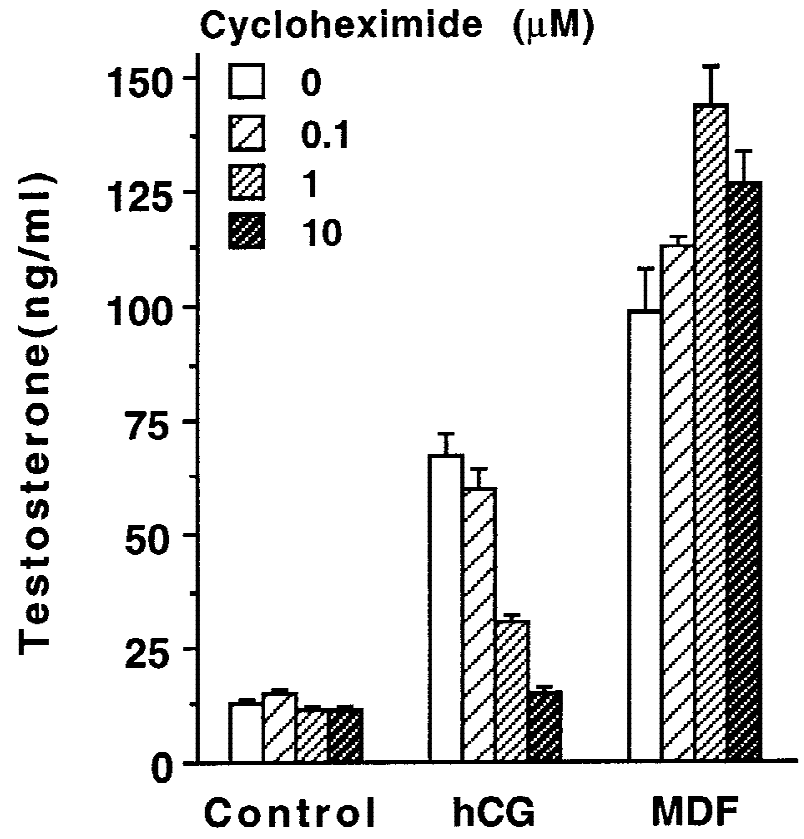

Figure 4 Effect of cycloheximide on the production of testosterone by Leydig cells cultured for $2 \mathrm{~h}$ in the presence of either hCG $(10 \mathrm{ng} / \mathrm{ml})$, or the macrophage-derived factor (MDF $1 \mathrm{unit} / \mathrm{ml}$ ). The means representing hCG-treated cells with both 1 and $10 \mu \mathrm{M}$ cycloheximide were statistically different $(P<0 \cdot 05)$ than the mean of hCG-treated cells in the absence of cycloheximide.

Similarly, the amount of StAR produced by MA-10 cells in response to the macrophage-derived factor was not different from the amount produced by control cultures (Fig. 5B). However, a dramatic increase in StAR production in MA-10 cells was observed with treatment with dbcAMP. Even though production of StAR did not increase with the macrophage-derived factor, an increase in progesterone production was observed (control, undetectable; macrophage-derived factor, $36 \cdot 6 \mathrm{ng} / \mathrm{ml})$.

Effect of the macrophage-derived factor in the presence of a CSCC inhibitor, or when CSCC activity was saturated with 22R-OHC

Neither the macrophage-derived factor nor hCG were able to increase testosterone production when CSCC was blocked with aminoglutethimide (Fig. 6). Near maximal inhibition was achieved with a dose of $40 \mu \mathrm{M}$, and with $400 \mu \mathrm{M}$ testosterone production remained at the level of the control cells. Aminoglutethimide also blocked the effects of the factor obtained from testicular macrophages and tested under similar conditions (data not shown).

Addition of 22R-OHC to untreated Leydig cells increased testosterone production 44-fold (Fig. 7). 

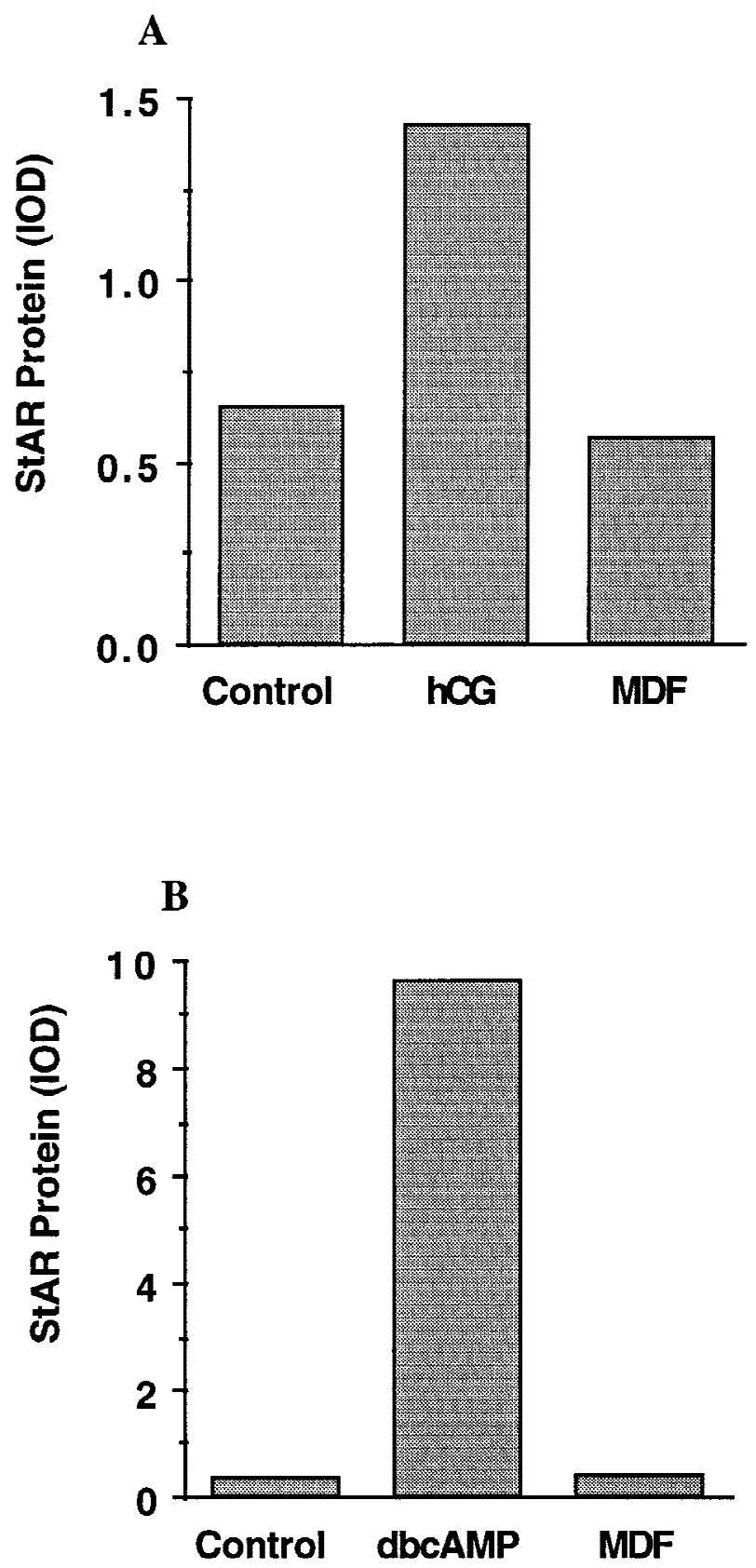

Figure 5 StAR production by Leydig cells (A) and MA-10 cells (B) in response to the macrophage-derived factor (MDF). Leydig cells were treated for $6 \mathrm{~h}$ with hCG $(1 \mathrm{ng} / \mathrm{ml})$ or MDF $(1 \mathrm{unit} / \mathrm{ml})$. MA-10 cells were treated for $6 \mathrm{~h}$ with dbcAMP $(1 \mathrm{mM})$ or MDF ( 1 unit/ml). The amount of StAR protein was determined by Western analysis. Autoradiograms were analyzed with the Visage 2000 image analyzer, and data from a representative gel were plotted as integrated units of optical density (IOD).

However, addition of the macrophage-derived factor caused no further stimulation of testosterone production when tested in the presence of a maximal dose of

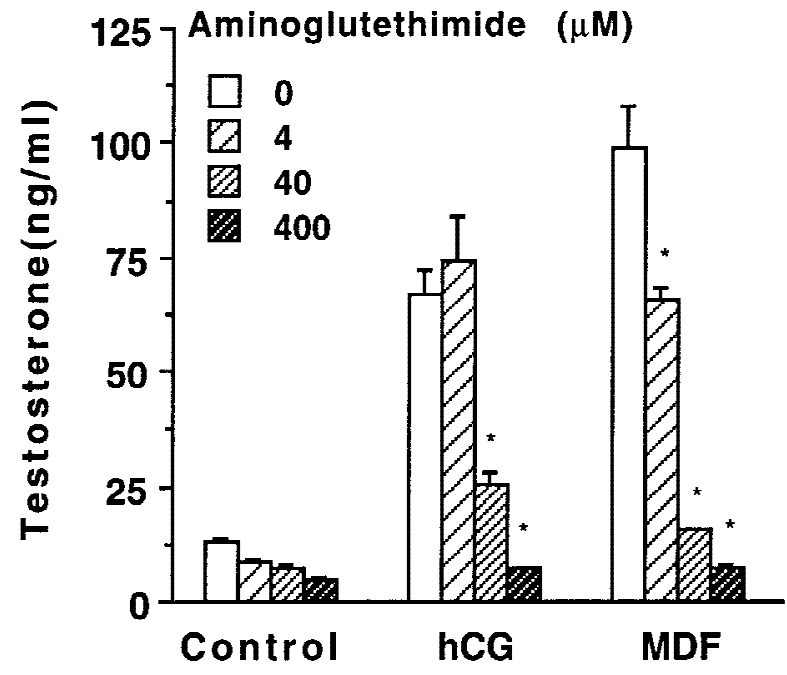

Figure 6 Effect of hCG $(10 \mathrm{ng} / \mathrm{ml})$ or the macrophage-derived factor (MDF, 1 unit/ml) on testosterone production by Leydig cells whose CSCC activity had been blocked with various concentrations of aminoglutethimide. Cells were treated for $6 \mathrm{~h}$. Asterisks indicate a statistically significant difference $(P<0 \cdot 05)$ when compared with the ' $O$ ' aminoglutethimide value within the same group.

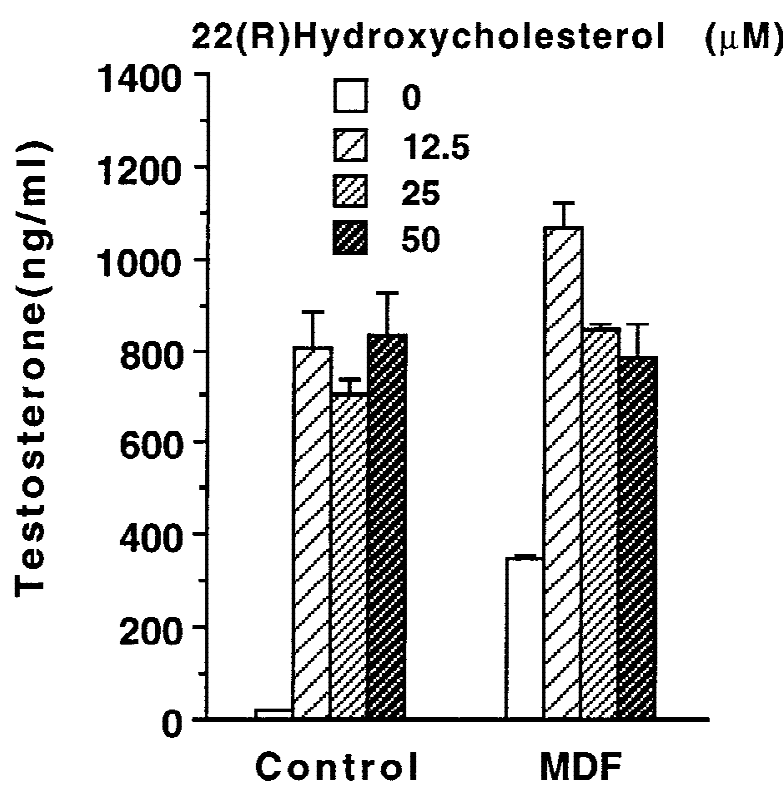

Figure 7 Effect of the macrophage-derived factor (MDF, 1 unit/ml) on testosterone production by Leydig cells whose CSCC was saturated with 22R-hydroxy-cholesterol. Cells were treated for $6 \mathrm{~h}$. There was no statistical difference between control and MDF at maximal saturation of the CSCC $(50 \mu \mathrm{M})$.

22R-OHC $(50 \mu \mathrm{M})$. Similar results were obtained when the factor was derived from testicular macrophages (data not shown). 


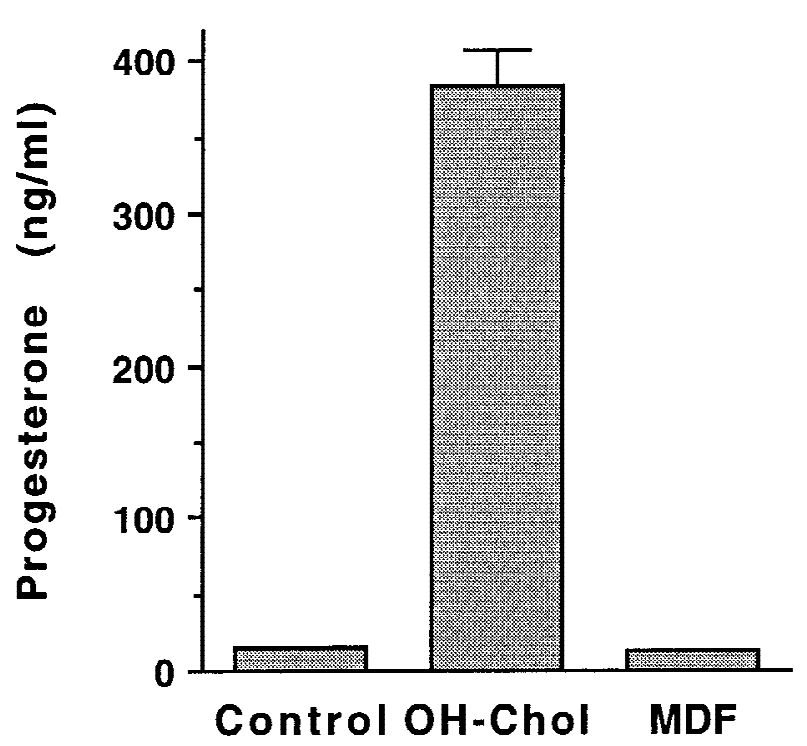

Figure 8 Effect of the macrophage-derived factor (MDF, 1 unit/ml) or 22R-hydroxy-cholesterol (OH-Chol, $25 \mu \mathrm{M})$ on progesterone production by isolated mitochondria from MA-10 cells treated for $1 \mathrm{~h}$.

Studies concerning the effects of the macrophage-derived factor on isolated mitochondria

The macrophage-derived factor did not have a direct effect on progesterone production by isolated mitochondria (Fig. 8). However, the mitochondria produced large amounts of progesterone in the presence of $22 \mathrm{R}-\mathrm{OHC}$ indicating that they were functionally capable of progesterone production (Fig. 8).

\section{Discussion}

The macrophage-derived factor induced major changes in testosterone production (equivalent to hCG), indicating that it has the potential to be an important regulator of steroidogenesis. Because a combined maximal dose of both hCG and the macrophage-derived factor was unable to stimulate more testosterone than that obtained with a maximal dose of the factor alone, it is possible that they both ultimately regulate a common restrictive site. However, because we found that the macrophage-derived factor increased testosterone production without stimulation of StAR, and was active in the presence of cycloheximide, it is clear that the macrophage-derived factor influences this common restrictive site through a very different pathway than that used by LH/hCG.

StAR-independent pathways have been reported previously. For example, steroidogenic-inducing protein, a factor isolated from human follicular fluid, was shown to stimulate progesterone production by MA-10 cells without activating cAMP or StAR (Stocco \& Khan 1992). Also, patients with functional mutations in the StAR gene still make small amounts of steroid (Bose et al. 1996) and, in MA-10 cells, approximately $10-20 \%$ of the maximal steroidogenic activity in response to hCG/cAMP remained when expression of StAR was blocked with actinomycin D (Clark et al. 1997). It has yet to be determined if these examples of StAR-independent pathways are the same pathways used by the macrophagederived factor, or if multiple StAR-independent pathways exist through which testosterone production can be regulated. Such pathways may be very important, since as discussed above, Leydig cells produced equal amounts of testosterone in the StAR-independent pathway (in response to the macrophage-derived factor) as they did through the StAR-dependent pathway (in response to hCG). It is also possible that the macrophage-derived factor acts through mechanisms associated with the peripheral benzodiazepine receptor pathway since this interesting mechanism is also known to be involved in steroidogenesis (Papadopoulos 1996). In this regard, calmidazolium, a compound that stimulates steroidogenesis in rat Leydig cells through a protein synthesis-independent mechanism (Choi \& Cooke 1992), binds to peripheral benzodiazepine receptors (Zisterer \& Williams 1997).

We found that the macrophage-derived factor was unable to stimulate steroidogenesis in the presence of aminoglutethimide, an inhibitor of cytochrome $\mathrm{P} 450_{\mathrm{scc}}$ activity (Uzgiris et al. 1977), indicating that the factor ultimately exerts its influence prior to this most important rate-limiting enzymatic step. Because 22R-OHC has relatively free access to the CSCC, it can saturate the

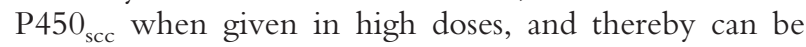
used to determine the capacity of this enzyme system (van Haren et al. 1992). Under such saturating conditions, we found that the macrophage-derived factor could not increase testosterone production further, indicating that the factor does not increase the ultimate capacity of the CSCC system.

We also tested the effects of the factor on MA-10 cells, a mouse Leydig cell tumor line that has been very useful for studies on steroid biogenesis (Ascoli 1981). Because the macrophage-derived factor stimulated progesterone production in these cells, but did not alter their level of StAR, it is possible that its site of action in these cells is similar, if not identical to the site of action in rat Leydig cells. This finding also indicates that the factor is not species restricted. Several lines of evidence indicate that the macrophage-derived factor is not a substrate for one of the various steps in the steroidogenic pathway from cholesterol to testosterone. For example, the factor elicited no response in rat Leydig cells in the presence of aminoglutethimide. Had the factor been a substrate for one of the enzymes down-stream to the CSCC enzymes, an increase would have been observed. Additional evidence that the factor is not simply a substrate for enzymes in the steroidogenic pathway distal to progesterone is provided 
by the finding that the macrophage-derived factor acted on MA-10 cells. MA-10 cells are capable of converting cholesterol to pregnenolone (which is then converted to progesterone), but have lost their cytochrome $\mathrm{P} 450$ $17 \alpha$-hydroxylase activity. Therefore, the major steroid produced in these cells is progesterone (Ascoli 1981, Mellon \& Vaisse 1989). Because of its nonpolar nature, cholesterol is unable to traverse the intermembranous aqueous fluid of the mitochondrion without assistance. Thus, it is also very unlikely that the macrophage-derived factor is a direct substrate for the $\mathrm{P} 450_{\mathrm{scc}}$ since this factor is even more nonpolar than cholesterol (Hutson et al. 1996). The fact that the factor was unable to directly alter steroidogenesis in isolated mitochondria further supports this conclusion. Taken together, these findings are consistent with the concept that the macrophage-derived factor is neither a substrate for steroidogenesis, nor does it act directly at the level of the mitochondria. Future studies are being directed towards determining if the factor exerts its influence through one of the many transduction pathways present in Leydig cells (Cooke 1996). We speculate that cAMP is not involved in mediating the actions of the macrophage-derived factor since cAMP is known to induce StAR synthesis (Fig. 5), and the macrophagederived factor appears to be StAR independent. However, it is possible that the macrophage-derived factor acts through a transduction system that is physically partitioned from the LH transduction pathway, a phenomenon known to exist in Leydig cells (Khanum \& Dufau 1987).

It was established long ago that $\mathrm{LH}$ is required for testosterone production by Leydig cells (Greep \& Fevold 1937). However, when testicular macrophages are depleted, testosterone levels are altered in that testis (Bergh et al. 1993, Cohen et al. 1996, Gaytan et al. 1996). Thus testicular macrophages, like $\mathrm{LH}$, are required for normal steroidogenesis. Because the macrophage-derived factor has a stimulatory action on Leydig cell steroidogenesis, it is tempting to speculate that it may mediate these actions of macrophages in vivo. However, macrophages are well known to produce a wide variety of bioactive factors. For example, IL-1 and TNFa have been shown to inhibit testosterone synthesis (for reviews see Hales 1996, Hedger 1997), and therefore may play very important roles when the macrophages are immunologically activated, such as during pathological conditions. These inhibitory cytokines may also be involved in the physiological regulation of testosterone production by countering the stimulatory influence of LH and the macrophage-derived factor. Determining the precise roles of these various factors will provide great insight into the local regulation of steroidogenesis by Leydig cells. In summary, we have found that the macrophage-derived factor elicits an acute and dramatic stimulatory effect on steroidogenesis in Leydig cells. While it requires an active CSCC system, it appears to act prior to this enzyme complex. Most notably, the factor acts without new synthesis of proteins, including StAR. The macrophage-derived factor is probably not a substrate for any of the enzymes in the steroidogenic pathway leading to the production of testosterone from cholesterol, and does not act directly at the level of the mitochondria. Studies are currently being conducted to determine the structure of this factor, and to determine how its actions are transduced.

\section{Acknowledgements}

This work was supported by grants from the Advanced Research Program from the Texas Higher Education Coordinating Board, and from the South Plains Foundation, Lubbock, TX to J C H; and by a grant from the NICHD to D M S (R37 HD17481).

\section{References}

Ascoli M 1981 Characterization of several clonal lines of cultured Leydig tumor cells: gonadotropin receptors and steroidogenic responses. Endocrinology 108 85-95.

Bergh A, Damber JE \& van Rooijen N 1993 Liposome-mediated macrophage depletion: an experimental approach to study the role of testicular macrophages. Journal of Endocrinology 136 407-413.

Bose H.S, Sugawara T, Strauss JF \& Miller WL 1996 The pathophysiology and genetics of congenital lipoid adrenal hyperplasia. New England Journal of Medicine $3351870-1878$.

Brigham DE, Little G, Lukyanenko YO \& Hutson JC 1997 Effects of clodronate-containing liposomes on testicular macrophages and Leydig cells in vitro. Journal of Endocrinology 155 87-92.

Choi MS \& Cooke BS 1992 Calmidazolium is a potent stimulator of steroidogenesis via mechanisms not involving cyclic AMP, calcium or protein synthesis. Biochemical Journal 281 291-296.

Clark BJ, Wells J, King SR \& Stocco DM 1994 The purification, cloning, and expression of a novel luteinizing hormone-induced mitochondrial protein in MA-10 mouse Leydig tumor cells. Journal of Biological Chemistry $26928314-28322$.

Clark BJ, Combs R \& Stocco DM 1997 Inhibition of transcription affects the synthesis of the Steroidogenic Acute Regulatory Protein (StAR) and steroidogenesis in MA-10 mouse Leydig tumor cells. Endocrinology 138 4893-4901.

Cohen PE, Chisholm O, Arceci RJ, Stanley ER \& Pollard JW 1996 Absence of colony-stimulating factor-1 in osteopetrotic (csfmop/csfmop) mice results in male fertility defects. Biology of Reproduction 55 310-317.

Cooke BA 1996 Transduction of the luteinizing hormone signal within the Leydig cell. In The Leydig Cell. pp 351-363. Eds A Payne, M Hardy \& L Russell. Vienna, Il: Cache River Press.

Gaytan F, Bellido C, Morales C, Garcia M, van Rooijen N \& Aguilar E 1996 In vitro manipulation (depletion versus activation) of testicular macrophages: central and local effects. Journal of Endocrinology 150 57-65.

Greep RO \& Fevold HL 1937 The spermatogenic and secretory function of the gonads of hypophysectomized adult rats treated with pituitary FSH and LH. Endocrinology 21 611-618.

Hales BD 1996 Leydig cell-macrophage interactions: an overview. In The Leydig Cell. pp 451-465. Eds A Payne, M Hardy \& L Russell. Vienna, Il: Cache River Press.

van Haren L, Flinterman JF, Orly J \& Rommerts FFG 1992 Luteinizing hormone induction of the cholesterol side-chain cleavage enzyme in cultured immature rat Leydig cells: no role of insulin-like growth factor-I. Molecular and Cellular Endocrinology 87 57-67. 
Hayes R, Chalmers SA, Nikolic-Paterson DJ, Atkins RC \& Hedger MP 1996 Secretion of bioactive interleukin-1 by rat testicular macrophages. Journal of Andrology 17 41-49.

Hedger MP 1997 Testicular leukocytes: what are they doing? Reviews of Reproduction 2 38-47.

Huhtaniemi I, Nikula H, Lehtonen E \& Hovatta O 1986 Testicular morphology and endocrine function after silica-induced damage of interstitial macrophages. In Molecular and Cellular Endocrinology of the Testis, pp 57-62. Eds M Stefanini, M Conti, R Geremia \& E Ziparo. Amsterdam: Elsevier.

Hutson JC 1989 Leydig cells do not have $\mathrm{F}_{\mathrm{c}}$ receptors. Journal of Andrology 10 159-165.

Hutson JC 1993 Secretion of tumor necrosis factor alpha by testicular macrophages. Journal of Reproductive Immunology 23 63-72.

Hutson JC 1994 Testicular macrophages. International Review of Cytology 149 99-143.

Hutson JC, Garner C \& Doris PA 1996 Purification and characterization of a lipophilic factor from testicular macrophages that stimulates testosterone secretion. Journal of Andrology 17 502-508.

Janszen FHA, Cooke BA, van Driel MJA \& van der Molen HJ 1976 LH induction of a specific protein (LH-IP) in rat testis Leydig cells. FEBS Letters 71 269-272.

Janszen FHA, Cooke BA \& van der Molen HJ 1977 Specific protein synthesis in isolated rat testis Leydig cells. Influence of luteinizing hormone and cycloheximide. Biochemical Journal 162 341-346.

Kern S, Robertson SA, Mau VJ \& Maddocks S 1995 Cytokine secretion by macrophages in the rat testis. Biology of Reproduction $\mathbf{5 3}$ $1407-1416$

Khanum A \& Dufau ML 1987 Inhibitory action of forskolin on adenylate cyclase activity and cyclic AMP generation. Journal of Biological Chemistry 261 11456-11459.

Mellon SH \& Vaisse C 1989 cAMP regulates P450 scc gene expression by a cycloheximide-insensitive mechanism in cultured mouse Leydig MA-10 cells. Proceedings of the National Academy of Sciences of the USA 86 7775-7779.

Moore C \& Hutson JC 1994 Physiological relevance of tumor necrosis factor in mediating macrophage-Leydig cell interactions. Endocrinology 134 63-69.
Pollard JW 1997 Role of colony-stimulating factor-1 in reproduction and development. Molecular Reproduction and Development $\mathbf{4 6}$ 54-61.

Papadopoulos V 1996 Peripheral-type benzodiazepine/diazepam binding inhibitor receptor: biological role in steroidogenic cell function. Endocrine Reviews 14 222-240.

van Rooijen N \& Sanders A 1997 Elimination, blocking, and activation of macrophages: three of a kind? Journal of Leukocyte Biology 62 702-709.

Stocco DM \& Khan SA 1992 Effects of steroidogenesis-inducing protein (SIP) on steroid production in MA-10 mouse Leydig tumor cells: utilization of a non-cAMP second messenger pathway. Molecular and Cellular Endocrinology 84 185-194.

Stocco DM \& Clark BJ 1996 Regulation of the acute production of steroids in steroidogenic cells. Endocrine Reviews 17 221-244.

Uzgiris VI, Whipple CA \& Salhanick HA 1977 Stereoselective inhibition of cholesterol side chain cleavage by enantiomers of aminoglutethimide. Endocrinology 101 89-92.

Verhoeven G, Cailleau J, Van Damme JV \& Billiau A 1988 Interleukin-1 stimulates steroidogenesis in cultured rat Leydig cells. Molecular and Cellular Endocrinology 57 51-60.

Xiong Y \& Hales DB 1993 Expression, regulation, and production of tumor necrosis factor- $\alpha$ in mouse testicular interstitial macrophages in vitro. Endocrinology 133 2568-2573.

Yee JB \& Hutson JC 1985 Effects of testicular macrophage-conditioned medium on Leydig cells in culture. Endocrinology 116 2682-2684.

Zisterer DB \& Williams DC 1997 Calmidazolium and other imidazole compounds effect steroidogenesis in Y1 cells: lack of involvement of the peripheral-type benzodiazepine receptor. Journal of Steroid Biochemistry and Molecular Biology 60 189-195.

Received 12 January 1998

Revised manuscript received 12 March 1998

Accepted 23 March 1998 